\title{
STANDARD CELLS.
}

By K. E. Guthe and C. L. von Ende.

I. According to recent investigations electrolytically prepared mercurous sulfate seems to be superior to chemically prepared sulfate as the depolarizer in standard cells ${ }^{1}$ and the first results of a series of observations on cadmium cells ${ }^{2}$ containing this substance showed for a period covering several months a remarkable agreement of their electromotive forces. For this reason one of the authors made use of Clark and cadmium cells with electrolytic mercurous sulfate for the determination of the electromotive forces of standard cells by absolute measurement. ${ }^{3}$

These cells have been transported from Washington to Iowa City, being carefully protected against mechanical disturbances. During the past winter they stood, however, for some weeks in diffused light and were exposed for a few days to large temperature variations. A comparison of the cells after this time showed that the electromotive force of the cadmium cells had decreased relatively with respect to that of the Clark cells, but accurate measurements could not be made at that time on account of lack of sufficiently sensitive instruments. The comparisons reported on in this paper were made with a calibrated Wolff potentiometer and a galvanometer allowing with certainty a reading to the fifth decimal place.

The cells were placed in a thermostat whose temperature could be kept constant at $25^{\circ} \mathrm{C}$. within 0.02 degrees. The temperature was measured by means of a thermometer subdivided into fiftieths of a degree and calibrated at the Bureau of Standards. Table I. shows the relative change of the electromotive forces of the cells in the interval of a year. The $\mathrm{R}$ series are Clark cells with electrolytic mercurous sulfate, $\mathrm{C}_{3}$ and $\mathrm{K}_{10}$ cadmium cells with chemically pre-

${ }^{1}$ Wolff, Trans. Amer. Electroch. Soc., 5, 49, r904. Carhart and Hulett, ibid., 5, 59, 1904. Hulett, Zeitschr. f. physik, Chem., 49, 483, I904; Phys. Rev., 22, 321, 1906. Compare also : Reichsanstaldt, Zeitschr. f. Instr. kunde, 26, I20, I906.

2 Carhart, Trans, Internat. Electr. Congr. St. Louis, vol. 2, 125, 1904.

${ }^{3}$ Guthe, Bull. Bur. Standards, vol. 2, 33, 1906. 
pared sulfate and the rest cadmium cells with the electrolytic material. More detailed information as to the construction of these cells may be found in the Bulletin of the Bureau of Standards, vol. 2, p. 60. Some of the cells have been set up by Professor Carhart, some by Professor Hulett. As reference value in the following table the electromotive force of the Clark cell as determined by absolute measurement was chosen, namely, I.42040 volts at $25^{\circ} \mathrm{C}$.

\section{TABLE I.}

Old Cells.

\begin{tabular}{|c|c|c|c|c|c|}
\hline & $\begin{array}{l}\text { Date of Con- } \\
\text { struction. }\end{array}$ & $\begin{array}{c}\text { September I7, } \\
\text { Igo5. }\end{array}$ & $\begin{array}{l}\text { October 15, } \\
\text { Igo6. }\end{array}$ & $\begin{array}{c}\text { November } 28, \\
\text { rgo6. }\end{array}$ & $\begin{array}{c}\text { January I2, } \\
\text { Ig07. }\end{array}$ \\
\hline $\mathrm{R}_{2}$ & \multirow{2}{*}{ May 1904.} & 1.42040 & 1.42040 & 1.42040 & 1.42040 \\
\hline $\mathrm{R}_{4}$ & & 40 & 40 & 40 & 41 \\
\hline $\mathrm{C}_{3}$ & \multirow{2}{*}{$\begin{array}{l}\text { Nov. } 1903 . \\
\text { Jan. } 1904 .\end{array}$} & 1.01857 & 1.01842 & 1.01844 & 1.01842 \\
\hline $\mathrm{E}_{2}$ & & 31 & 04 & 01 & 1789 \\
\hline $\mathrm{F}_{8}$ & \multirow{2}{*}{ Feb. 1904.} & 27 & 19 & 22 & 1822 \\
\hline$F_{9}$ & & 28 & 08 & 07 & 1799 \\
\hline $\mathrm{K}_{6}$ & \multirow{2}{*}{ July 1904} & 33 & 24 & 25 & 1826 \\
\hline $\mathrm{K}_{10}$ & & 33 & 11 & 12 & 02 \\
\hline $\mathrm{O}_{1}$ & \multirow{2}{*}{ Feb. 1905.} & 33 & 23 & 23 & 24 \\
\hline $\mathrm{O}_{2}$ & & 33 & 19 & 22 & 21 \\
\hline
\end{tabular}

The change in most of the cadmium cells amounts to about $0.000 \mathrm{I}$ volt. Since the potentiometer was carefully calibrated and the thermometer correction known, this change is larger than the possible error in the apparatus. The relative values of $\mathrm{F}_{8}, \mathrm{~K}_{6} \mathrm{O}_{1}$ and $\mathrm{O}_{2}$ have remained about the same as last year, but for the others the decrease has been larger and quite irregular.

2. To decide the question if a change had taken place in the Clark cells chosen as reference standards it became necessary to construct new standard cells. At the same time we wished to ascertain how closely such cells would agree in electromotive force if constructed by different observers and with material from different sources. No such comparative investigation has yet been published so far as we know.

Professor Hulett kindly sent us some of his electrolytic mercurous sulphate and we prepared two different lots following closely the method published by him. We shall designate these two as lot I and 2 respectively. The sulfate was made from pure mercury in an 
acid prepared by mixing one part of concentrated sulfuric acid of specific gravity I.84 with six times its volume of distilled water. The current density was between two and three amperes per Ioo square centimeters. The first lot consisted of very fine crystals; the second was stirred longer after the breaking of the current and was therefore coarser.

The sulfate was filtered in a Gooch crucible and after the acid had been thoroughly drained off, was washed repeatedly with alcohol and saturated zinc or cadmium sulfate solution. We found it necessary to be very careful in washing, especially with the finest crystals. After the last washing with the salt solution the top layer was removed and the paste prepared in the usual manner.

The mercury was either distilled by Hulett's method ${ }^{1}$ or distilled twice in vacuo in an ordinary mercury still.

The zinc amalgam was prepared in the usual way by dissolving zinc in mercury. In some of the cadmium cells we used an amalgam prepared electrolytically.

\section{Clark Cells.}

3. Two series were set up, the $a$ and $b$ series. In the $a$ series the zink amalgam contained 9 per cent. of zinc. Our mercurous sulfate No. I was used in the $a$ series. In the $b$ series the amalgam contained Io per cent. of zinc, and Hulett's mercurous sulfate was used. Mercury distilled by Hulett's method was used in cells $a_{1}$, $a_{2}, b_{1}$ and $b_{2}$, the other mercury in $a_{3}$ and $b_{3}$. The zinc sulfate crystals were recrystallized from a neutralized solution of Schuchardt's c. p. sulfate and the solution in the cells made from these crystals.

In table II, the electromotive forces as determined on different days are tabulated. The values for the cells with the very fine mercurous sulfate were at first somewhat low, but increased rather suddenly between the ninth and fourteenth day, then slower until they reach a value a little higher, but still agreeing well with that of the old Clark cells. The $b$ cells, the mercurous sulfate of which had not been as difficult to wash, had immediately after construction a value agreeing within 0.00003 volt with that of the old cells and remained constant ever since.

${ }^{1}$ Hulett and Minchin, Phys. Rev., 21, 388, 1905. 
The great difference in the size of the mercurous sulfate crystals had apparently no great influence upon the final value of the electromotive force ; the two different samples of mercury behaved electrolytically exactly alike.

TABLE II.

Clark Cells.

\begin{tabular}{|c|c|c|c|c|c|c|c|}
\hline & $\begin{array}{c}\text { Date of } \\
\text { Construction. }\end{array}$ & $\begin{array}{l}\text { Oct. I4, } \\
\text { Igo6. }\end{array}$ & $\begin{array}{l}\text { Oct. 2o, } \\
\text { Igo6. }\end{array}$ & $\begin{array}{l}\text { Oct. } 26, \\
\text { 1906. }\end{array}$ & \multicolumn{2}{|c|}{$\begin{array}{l}\text { Nov. } 6 \text {, } \\
\text { Igo6. }\end{array}$} & $\begin{array}{l}\text { Nov. } 20, \\
\text { 1906. }\end{array}$ \\
\hline$a_{1}$ & \multirow{3}{*}{ Oct. 13, 1906} & 1.42025 & 1.42029 & 1.42037 & \multicolumn{2}{|c|}{1.42041} & 1.42043 \\
\hline$a_{2}$ & & - & - & - & & 40 & 43 \\
\hline$a_{3}$ & & \multirow[t]{4}{*}{24} & 30 & 38 & & 42 & 43 \\
\hline$b_{1}$ & \multirow{3}{*}{ Oct. 19,1906} & & 38 & 39 & & 38 & 38 \\
\hline $\mathrm{b}_{2}$ & & & 37 & 40 & & 39 & 38 \\
\hline \multirow[t]{2}{*}{$b_{3}$} & & & 37 & 39 & & 38 & 38 \\
\hline & \multicolumn{2}{|c|}{ Date of Construction. } & Jec. $5,1906$. & \multicolumn{2}{|c|}{ Dec. 24, 1906.} & \multicolumn{2}{|c|}{ Jan. $19,1907}$. \\
\hline$a_{1}$ & \multirow{2}{*}{\multicolumn{2}{|c|}{ Oct. 13, 1906}} & 1.42044 & \multicolumn{2}{|c|}{1.42045} & \multicolumn{2}{|c|}{1.42045} \\
\hline$a_{2}$ & & & 44 & \multicolumn{2}{|c|}{45} & \multicolumn{2}{|r|}{45} \\
\hline$a_{3}$ & & & 45 & \multicolumn{2}{|c|}{44} & \multicolumn{2}{|r|}{45} \\
\hline$b_{1}$ & \multirow{3}{*}{\multicolumn{2}{|c|}{ Oct. 19, 1906}} & 38 & \multicolumn{2}{|c|}{38} & \multicolumn{2}{|r|}{-} \\
\hline $\mathrm{b}_{2}$ & & & 38 & \multicolumn{2}{|c|}{38} & \multicolumn{2}{|r|}{38} \\
\hline $\mathrm{b}_{3}$ & & & 37 & \multicolumn{2}{|c|}{38} & & 38 \\
\hline
\end{tabular}

We also prepared some cells in which the directions were not followed very closely. In $a_{4}, a_{5}$, and $a_{6}$ the mercurous sulfate (Hulett's) was not thoroughly freed from alcohol which produced a lowering of the electromotive force by over 0.00040 volt without an appreciable change in course of time. Cells $b_{4}$ and $b_{5}$ were prepared with our mercurous sulfate No. I, thoroughly washed but it was mixed with about the same bulk of zinc sulfate crystals and the paste made very thin. These cells had from the start an electromotive force 0.00015 volt higher than the normal value and remained perfectly constant.

It is apparent that the treatment of the mercurous sulfate plays a much more important rôle than the sulfate in itself. $a_{1}, a_{2}$ and $a_{3}$ as well as $b_{4}$ and $b_{5}$ were made with our sulfate, but the former cells show quite a different behavior from that of the latter; the same is true of the cells in which Hulett's sulfate was used.

After a few weeks $a_{3} a_{4}$ and $a_{5}$ as well as $b_{4}$ and $b_{5}$ were placed for three hours on a circuit of 1,000 ohms external resistance Nov. 4 and Nov. 23 respectively. It was hoped that, if free acid had 
TABLE III.

Clark Cells.

\begin{tabular}{|c|c|c|c|c|c|c|}
\hline & $\begin{array}{l}\text { Date of } \\
\text { Construction. }\end{array}$ & $\begin{array}{l}\text { Oct. I4, } \\
\text { rgo6. }\end{array}$ & $\begin{array}{l}\text { Oct. 18, } \\
\text { Igo6. }\end{array}$ & $\begin{array}{c}\text { Oct. } \\
\text { Igo }\end{array}$ & $\begin{array}{l}\text { Oct. } 26, \\
\text { Igo6. }\end{array}$ & $\begin{array}{l}\text { Nov. } 6 \text {, } \\
\text { Igo6. }\end{array}$ \\
\hline \multirow{6}{*}{$\begin{array}{l}a_{4} \\
a_{5} \\
a_{6} \\
b_{4} \\
b_{5}\end{array}$} & \multirow{3}{*}{ Oct. 13, 1906} & 1.41968 & 1.41992 & 1.41992 & 1.41994 & 1.41982 \\
\hline & & 80 & 1.42004 & 1.42003 & 99 & 80 \\
\hline & & 87 & \multirow[t]{3}{*}{06} & 05 & 1.42005 & 93 \\
\hline & \multirow{2}{*}{ Oct. 19, 1906} & & & \multirow{2}{*}{$\begin{array}{r}1.42056 \\
56\end{array}$} & 1.42057 & 1.42056 \\
\hline & & & & & 57 & 56 \\
\hline & $\begin{array}{c}\text { Date of } \\
\text { Construction. }\end{array}$ & Nov. 23, rgo6. & \multicolumn{2}{|c|}{ Dec. 5, rgo6. } & $\begin{array}{l}\text { Dec. 24, } \\
\text { I906. }\end{array}$ & $\begin{array}{c}\text { Jan. I9, } \\
\text { I907. }\end{array}$ \\
\hline$a_{4}$ & \multirow{3}{*}{ Oct. 13, 1906} & 1.41980 & \multicolumn{2}{|c|}{1.41981} & 1.41980 & 1.41980 \\
\hline$a_{5}$ & & 80 & \multicolumn{2}{|c|}{81} & 81 & 80 \\
\hline$a_{6}$ & & 91 & \multicolumn{2}{|c|}{91} & 91 & 91 \\
\hline$b_{4}$ & \multirow{2}{*}{ Oct. 19, 1906} & 1.42053 & \multirow{2}{*}{\multicolumn{2}{|c|}{$\begin{array}{r}1.42054 \\
54\end{array}$}} & 1.42055 & 1.42054 \\
\hline$b_{5}$ & & 53 & & & 54 & 54 \\
\hline
\end{tabular}

been present, this treatment would change the electromotive force. After opening the circuit the electromotive force had dropped about 0.00040 volt, but it returned in about two hours to about its original value and remained constant after that.

\section{Cadmium Cells.}

4. The cadmium sulfate crystals were obtained from three different solutions; of these $A$ was made from Merck's pure cadmium sulfate, $B$ from Baker's c. p. material, and $C$ from mixed turbid crystals picked out from either $A$ or $B$. In the $c$ series lot 2 of our electrolytic mercurous sulfate washed with alcohol and saturated cadmium sulfate solution (made from selected clear crystals) was used. The amalgam contained I 2.5 per cent. cadmium and was made by dissolving Kahlbaum's cadmium (käufflich) in warm mercury.

Since it is rather troublesome to obtain a sufficient number of perfectly clear crystals from a small bulk of cadmium sulfate solution, we used also somewhat turbid crystals. The crystals in $c_{1}$ were selected large clear crystals from solution $C$, in $c_{2}$ small selected, somewhat turbid crystals from solution $B$, and in $c_{3}$ large selected crystals somewhat cloudy, from $A$ and $C$.

In the $d$ series Hulett's mercurous sulfate was used, treated the same way as ours in the $c$ series. In $d_{1}$ and $d_{2}$ selected clear crys- 
tals were used from solution $C$, in $d_{3}$ and $d_{4}$ small crystals which had been formed at the bottom of the crystallizing dish from solution $A$ and which were washed a few times with distilled water, after the mother liquor had been filtered off. No attempt was made to select the crystals for these cells. The solution in the cells was always made from the crystals used in filling. $d_{1}$ and $d_{3}$ contain the same amalgam as the $c$ cells, $d_{2}$ and $d_{4}$ electrolytically prepared amalgam.

Table IV. shows that the cadmium cells $c$ gave at first a value for the electromotive force of nearly I.0I 840 volt. which dropped, however, within a few days by about $0.000 \mathrm{I}$ volt. and remained fairly constant after that. The drop in the $d$ cells is, however, considerably larger than in the $c$ cells, and especially pronounced in $d_{3}$ and $d_{4}$. The different methods of preparing the amalgam does not seem to have an effect upon the electromotive force. ${ }^{1}$

TABLE IV.

Cadmium Cells.

\begin{tabular}{|c|c|c|c|c|c|c|}
\hline & $\begin{array}{c}\text { Date of } \\
\text { Construction. }\end{array}$ & $\begin{array}{l}\text { Nov. } 3 \text {, } \\
\text { rgo6. }\end{array}$ & $\begin{array}{l}\text { Nov. } 6, \\
\text { rgo6. }\end{array}$ & $\begin{array}{l}\text { Nov. ro, } \\
\text { rgo6. }\end{array}$ & $\begin{array}{l}\text { Nov. I2, } \\
\text { 1906. }\end{array}$ & $\begin{array}{l}\text { Nov. I7, } \\
\text { Igo6. }\end{array}$ \\
\hline \multirow{8}{*}{$\begin{array}{l}\mathrm{c}_{1} \\
\mathrm{c}_{2} \\
\mathrm{c}_{3} \\
\mathrm{~d}_{1} \\
\mathrm{~d}_{2} \\
\mathrm{~d}_{3} \\
\mathrm{~d}_{4}\end{array}$} & \multirow{3}{*}{ Nov. 2, 1906} & 1.01840 & 1.01838 & 1.01836 & 1.01835 & 1.01835 \\
\hline & & 38 & 36 & 35 & 34 & 35 \\
\hline & & 39 & 37 & 36 & 33 & 33 \\
\hline & \multirow{4}{*}{ Nov. 9, 1906} & & \multirow{4}{*}{. } & 1.01842 & 1.01840 & 1.01834 \\
\hline & & & & 42 & 42 & 37 \\
\hline & & & & 46 & 40 & 28 \\
\hline & & & & 47 & 45 & 35 \\
\hline & $\begin{array}{c}\text { Date of } \\
\text { Construction. }\end{array}$ & $\begin{array}{l}\text { Nov. } 23 \\
\text { rgo6. }\end{array}$ & $\begin{array}{l}\text { Nov. } 28, \\
\text { Igo6. }\end{array}$ & $\begin{array}{l}\text { Dec. } 5 \text {, } \\
\text { Igo6. }\end{array}$ & $\begin{array}{l}\text { Dec. I3, } \\
\text { 1906. }\end{array}$ & $\begin{array}{l}\text { Jan. rg, } \\
\text { rgo7. }\end{array}$ \\
\hline$c_{1}$ & \multirow{3}{*}{ Nov. 2, 1906} & 1.01834 & 1.01833 & 1.01831 & 1.01829 & \\
\hline $\mathrm{c}_{2}$ & & 35 & 34 & 32 & 30 & 1.01829 \\
\hline$c_{3}$ & & 32 & 32 & 31 & 28 & 28 \\
\hline $\mathrm{d}_{1}$ & \multirow{4}{*}{ Nov. 9. 1906} & 1.01827 & 1.01823 & 1.01815 & 1.01811 & 1.01805 \\
\hline $\mathrm{d}_{2}$ & & 33 & 31 & 24 & 19 & 13 \\
\hline $\mathrm{d}_{3}$ & & 19 & 14 & 10 & 06 & 03 \\
\hline$d_{4}$ & & 24 & 19 & 11 & 07 & 02 \\
\hline
\end{tabular}

1 Towards the end of December, 1906, we exchanged Clark cell $b_{1}$ and cadmium cell $c_{1}$ for a Clark and cadmium cell constructed by Dr. Wolff at the Bureau of Standards. Wolff's Clark cell has an electromotive force 0.00006 volt. lower, and his cadmium cell an electromotive force 0.00003 volt. lower than ours of the same type. Dr. Wolff writes that he has found practically the same difference in his comparisons at the Bureau which shows that the cells have not been affected by transportation. 
5. In a general way this investigation corroborates Hulett's recently published results, ${ }^{1}$ that Clark cells containing electrolytic mercurous sulfate when set up with proper precautions will have an electromotive force of $\mathrm{I} .42040$ volts at $25^{\circ} \mathrm{C}$. within a few onehundred thousandths of a volt and remain constant in course of time. The cadmium cells show immediately after the setting up of an electromotive force of I.OI84 volts, closely agreeing with the value given by Hulett.

There is, however, one notable difference. Hulett's $A$ cells, set up October 2I, I905, have an electromotive force of I.0I 843 volts and have kept this value for at least six months, later results not having been published. His old cells ( $F$ series) are now about 0.000 I I volt lower. Hulett, therefore, drew the conclusion that in the course of time the electromotive force slowly decreases and described a number of very interesting experiments which seem to show that the system in the cathode leg of the cells is not in equilibrium. But the $F$ cells, though originally of the same high value, decreased to their present low value within a week, and have remained, with one exception, constant since then. A similar rapid decrease is noticeable in the $J$ and $K$ cells on which Professor Carhart ${ }^{2}$ has reported. Hulett explains this difference in behavior by a difference in the depth of the paste. We have made the paste in the cells over two centimeters deep, but nevertheless the initial decrease is rapid. This difference in the behavior of Hulett's and our cells can hardly be due to the mercurous sulfate and we are at a loss to explain it unless it is to be found in the unstable equilibrium between the cadmium sulfate solution and the rest of the material at the cathode or in a difference in the method of construction of which we are not aware. Our results do not extend over a sufficiently long period to decide the question whether or not there will be a continuous slow decrease of the electromotive force in course of time.

After the satisfactory results obtained with the Clark cells the apparent difficulty for different observers to set up cadmium cells, which remains constant from the start and are practically identical

\footnotetext{
${ }^{1}$ Hulett, Phys. Rev., 23, 166, 1906.

${ }^{2}$ Carhart, 1. c.
} 
in their electrical behavior, seems to indicate that there is still some factor of uncertainty in the method of construction for the latter and this demands further investigation.

The large changes in the electromotive forces of the old cadmium cells mentioned above, are, possibly, not due to a continuous gradual decrease in course of time but to sudden changes brought about by the severe treatment to which they were subjected. It is however very gratifying to know that the causes for such changes have had no influence whatever upon the electromotive force of the Clark cells, since the latter agree so closely with the newly prepared cells.

\section{Conclusions.}

I. The electromotive forces of standard cells set up with electrolytic mercurous sulfate by different observers and from different sources agree under otherwise perfectly equal conditions within a few one hundred-thousands of a volt.

2. Mercury twice distilled in an ordinary vacuum still gives the same results as mercury distilled by Hulett's method.

3. Amalgam prepared in the usual way gives the same results as electrolytic amalgam.

4. Clear and cloudy cadmium sulfate crystals produce no difference in the electromotive force of the cadmium cells.

5. Clark cells with electrolytic, coarsely grained mercurous sulfate have immediately after construction an electromotive force of I. 4204 volts at $25^{\circ} \mathrm{C}$. within a few one hundred-thousandths of a volt and remain constant in course of time.

6. We have been unable to construct cadmium cells which do not show an identical decrease in electromotive force.

The State University of Iowa, IowA City, January, 1907 . 